\title{
Global Education Governance in the Context of COVID-19: Tensions and Threats to Education as a Public Good
}

\author{
Antonia Wulff ${ }^{1}$ \\ Published online: 8 June 2021 \\ (c) Society for International Development 2021
}

\begin{abstract}
This article discusses the failure of global governance to defend and reinforce education as a public good and its public provision and regulation. Challenging the framing of states and the private sector as being equally important for the achievement of the SDGs, it calls for a reimagination of the role of global governance and an accountability structure that places the economic, social and environmental consequences of policy and financing modalities at the centre.
\end{abstract}

Keywords SDG $4 \cdot$ Financing $\cdot$ Privatization $\cdot$ Edtech

The anticipated Decade of Action and Delivery, launched by the UN Secretary-General to advance progress towards the Sustainable Development Goals (SDGs) by 2030, came to an abrupt halt as the COVID-19 pandemic advanced across the globe. What started as a public health crisis quickly morphed into political, economic and social crises, with far-reaching impacts on the lives and livelihoods of people and communities across the globe.

As part of this, an education crisis unfolded: at the beginning of April, all schools and education institutions were closed in 194 countries, affecting almost 1.6 billion students, which amounts to $91.3 \%$ of the global student population. ${ }^{1}$ This is unprecedented: never before have schools been closed to this extent or has such a rapid and large-scale shift of education to an online format taken place, fundamentally changing the nature and conditions of teaching and learning.

Such a crisis provides ample opportunity for all those who are aiming to influence or change the provision of public education. International organizations in the global education landscape are stepping up their game to prove their relevance and consolidate their status as experts, while a number of private actors are positioning themselves as essential partners in the emergency response.

The UN was quick to assert that the world would have been better prepared for the pandemic had more progress

Antonia Wulff

Antonia.Wulff@ei-ie.org

1 Education International, Brussels, Belgium been made to date towards the SDGs. ${ }^{2}$ It is true that the pandemic is likely to have developed differently had Member States delivered on their commitments to universal healthcare, quality education, gender equality and decent work, inter alia. However, this article takes as its point of departure that the desired progress was undermined long before the outbreak of COVID-19 through the renegotiation and weakening of the role of the state as also reflected in the adoption of the 2030 Agenda.

Education is traditionally a domain of the government, where public authorities determine how education is organized and quality assured. This is in line with a rights-based approach: governments are the duty-bearers and as such, are responsible for ensuring the right to education. While governments have succeeded in making education more accessible over the past decades, the role of the government has also been changing as public budgets were shrinking and the private sector encouraged and facilitated to play a new and expanded role in public policy implementation. I argue that this development has been reinforced by the global governance of education, which has failed to defend the public nature of education and the necessary related public investment, and blurred the distinction between the responsibilities of states and non-state actors.

Discussing global education governance in the context of COVID-19, I consider the pandemic a proxy for a new

\footnotetext{
${ }_{1}$ https://en.unesco.org/covid19/educationresponse. Accessed 25 April 2020.

${ }^{2}$ https://unsdg.un.org/sites/default/files/2020-04/UN-frameworkfor-the-immediate-socio-economic-response-to-COVID-19.pdf. Accessed 10 June 2020.
} 
normal, where the climate crisis and a range of associated disasters are likely to result in regular, albeit temporary, school closures. I start by providing a brief overview of the education landscape, with a focus on the architecture around the implementation and monitoring of SDG 4. Looking specifically at a changing governance landscape, I then discuss the COVID-19 response of UNESCO and policy developments in two areas where a renegotiation of the role of the state can be observed: the introduction of technology in education, and education financing. As I conclude, I reflect on the failure of the global governance in promoting and protecting education as a right and a public good and I call for a reimagination of the role of global governance as one that reinforces the values and principles of Agenda 2030, addresses systemic barriers and interrogates the suitability of privately financed public goods and their implications for the social contract.

\section{The Global Governance of Education: The SDG 4 Architecture}

Education is a central development priority, as reflected in global development agendas over recent decades. The current one, the 2030 Agenda for Sustainable Development, provides a structure for global education governance, complete with a shared set of priorities, an agreed timeline and a range of mechanisms for monitoring and follow-up, including indicators. The reality is, however, messy and multifaceted.

The SDGs were adopted in a political context where major multilateral agreements had become increasingly rare, making weak accountability and reporting frameworks a precondition for the adoption of any agenda. As a result, the broad and ambitious priorities within the SDGs and associated targets are not tied to specific policies, implementation modalities or financing arrangements. Member States rejected both the language and the notion of accountability, opting instead for the rather obscure follow-up and review, which is to be "voluntary and country-led, will take into account different national realities, capacities and levels of development and will respect policy space and priorities' (UNGA 2015: para 74.a).

Despite the formal allegiance to the SDGs and its education goal, SDG 4, agreement continues to be sought as to what the new agenda means in practice, and what it will take to succeed. UNESCO's roadmap for SDG 4 implementation, the Education 2030 Framework for Action, calls on governments to 'sustain political leadership on education and guide the process of contextualizing and implementing the SDG 4-Education 2030 goal and targets, based on national experiences and priorities' (UNESCO 2015b: 57). Such a contextualization is a precondition for relevant and targeted implementation. But it also risks undermining the agenda and the whole notion of shared priorities. UNESCO's efforts to prevent this and guide a coordinated and coherent implementation have fallen short and there is little indication of its Framework having become the normative instrument that it was designed to be.

If there is minimal accountability for Member States, there is even less for international organizations. There is an important difference between governments adapting global goals to their national circumstances, and the tendency of international organizations to pick and choose among the priorities within SDG 4. Despite the direct involvement of UN agencies, the World Bank and the OECD in SDG 4 governance, their different mandates and ideological approaches shape their respective SDG 4 efforts to the extent that they risk undermining its purpose-inclusion, equity and quality in education (Wulff 2019). The global governance has a crucial role to play in promoting and defending the values underpinning the SDGs, such as a rights-based approach. Every initiative need not reflect the full scope of SDG4, but the global governance cannot assume that every education initiative automatically contributes to the achievement of SDG4.

\section{SDG Implementation: A Free-for-all}

The weak accountability framework is compounded by the emphasis within the SDGs on everybody contributing: all actors are framed as equally important and all implementation is considered good implementation. Governments are mentioned only a handful times in the 2030 Agenda and in a majority of cases they are followed by the private sector, civil society, the UN system and other actors-all those who are called upon to join a Global Partnership and mobilize all available resources for the implementation of the Agenda. ${ }^{3}$ The only areas where governments are framed as directly responsible are the follow-up and review ${ }^{4}$ and the setting of national targets and their incorporation into 'national planning processes, policies and strategies ${ }^{5}$; the former is ironic given that it is their own efforts they should be monitoring.

Such a framing of all actors as equally important reflects a renegotiation of the role of the state, overlooking its responsibilities as the duty-bearer in relation to the commitments within the 2030 Agenda. The UN Special Rapporteur on

\footnotetext{
3 https://sustainabledevelopment.un.org/post2015/transformingour world. Accessed 10 June 2020, para 39.

${ }^{4}$ https://sustainabledevelopment.un.org/post2015/transformingour world, para 47.

5 https://sustainabledevelopment.un.org/post2015/transformingour world, para 55 .
} 
Extreme Poverty and Human Rights has argued that when private actors and organizations enter public spaces and government domains, there is a more ideological dynamic at play, where power is being renegotiated, simply through the new role taken by the private sector, and its implicit or explicit sidelining of the government (UN 2018).

In negotiations leading up to the adoption of the 2030 Agenda, Member States were explicit in their preference for outcomes-based indicators to accompany the 169 targets. This fits neatly with a results-based and impact-driven understanding of development, where the how and the who are framed as irrelevant so long as the results are obtained. While there is little to suggest that the indicators themselves have played the intended role as the mechanism for monitoring and assessing progress, the emphasis on results has characterized the discourse at the High Level Political Forum (HLPF).

But progress is not neutral, and development is not apolitical. The modalities of implementation are deeply ideological and only by recognizing this can progress be assessed and measured; policy choices-sources of funding, the provider of services, the quality and level of inclusivity, inter alia-determine whether inequality and discrimination are reproduced and ossified. It is essential that the follow-up and review processes address structural barriers and power imbalances, contradictions between targets and unintended consequences of implementation strategies.

The role of global governance must not be to depoliticize development or delegitimize the concerns and grievances of people and popular movements. The follow-up and review process pledges to be 'people-centred, gender-sensitive, respect human rights and have a particular focus on the poorest, most vulnerable and those furthest behind ${ }^{9}{ }^{6}$ Delivering on this requires a different understanding of how progress is measured, starting with accountability for governments and human rights as the framework for ensuring equitable development. Given that 156 of the 169 targets have substantial linkages to human rights and labour standards, human rights mechanisms should be an integral part of the accountability architecture around the SDGs (Feiring and Hassler 2016).

Global governance of the SDGs must address the fundamental imbalance in power and resources between countries. For the follow-up and review to make any sense, there has to be a political mandate to discuss systemic barriers and the limited progress made in the past decades, despite the world being richer than it has ever been before. More attention must also be paid to the impact beyond the nation state and its borders, recognizing that the world is interdependent—and deeply unequal.

\footnotetext{
${ }^{6}$ https://sustainabledevelopment.un.org/post2015/transformingour world, para 74.e.
}

\section{Teaching and Learning in a Pandemic: An Education Crisis}

The extraordinary scale of school closures following the pandemic has demonstrated the many roles and the indisputable value of school as a physical place. Beyond the obvious interruption in learning, the closures have had a number of adverse impacts, such as social isolation and its impact on social and behavioural development; the absence of school meals and its impact on family income and women's unpaid work; the loss of a safe environment; the gaps in childcare and their impact on work and life balance, particularly for women; and a rise in child labour and child marriage. Many girls will have taken up domestic and care work duties, which is likely to result in higher dropout rates among girls too. $^{7}$

Crisis is nothing new to education, particularly not to public education systems, which are the regular victims of both real crises-such as funding cuts and shortages of qualified teachers-and manufactured crises, such as those being declared in relation to global learning metrics (Benavot and Smith 2020). A crisis is always an opportunity-to cut costs, rethink current operations and push through reforms that have proven hard to sell in the past. Over the past several years, a number of non-state actors have been quick to grab this opportunity, often with the implicit understanding that the state is to blame for the crisis.

The responses to the pandemic mirror the competing conceptions of quality education that defined the process leading up to the adoption of SDG 4 and continue to shape its implementation (Sayed and Moriarty 2020). The tension between a rights-based and an instrumentalist approach to education is reflected in the often-conflicting efforts to enhance quality and maximize learning. Consequently, there has been disproportionate attention to the anticipated learning gaps, with the UNESCO Institute for Statistics arguing that "quick and short tests for the frequent measurement of student learning' are essential education data to be collected during the COVID-19 crisis $^{8}$ and the World Bank worrying about the impact on future human capital and calling for simplified curricula, enhanced 'efficiency of classroom instruction' and data to track learning (World Bank 2020: 34).

At the same time, many teachers have cautioned against a sole focus on learning gaps, arguing that the primary needs of students may be socio-emotional rather than academic, and positing well-being as the basis for any teaching and

\footnotetext{
${ }^{7}$ https://en.unesco.org/news/covid-19-school-closures-around-worldwill-hit-girls-hardest. Accessed 10 June 2020.

8 http://uis.unesco.org/en/files/fs58-need-essential-education-datapdf- 0 . Accessed 10 June 2020.
} 
learning. ${ }^{9}$ According to the Alberta Teachers Association in Canada, for instance, around three quarters of teachers report a decrease in emotional connection with their students and a decline in students' ability to focus. ${ }^{10}$

The sudden and complete reliance on technology and online platforms quickly revealed the stark differences in students' ability to do schoolwork, access devices and the internet and enjoy support from adults at home-placing inequity in education at the centre of policy debates. The risk is that the glaring digital divide conceals the deeper structures of inequity by creating an impression of universal access to education technology (edtech) and devices being the only necessary policy response to inequity. Most education systems were deeply unequal before the pandemic too. The gap in reading performance between the $10 \%$ most socio-economically advantaged and the $10 \%$ most disadvantaged students in France, Germany, Hungary, Israel, Peru and the Slovak Republic corresponded to more than four years of schooling (Scheicher 2019: 19) In fact, every summer holiday represents a retrogression in equity, where the gap in literacy levels widens between those from higher socioeconomic backgrounds and those from lower socioeconomic backgrounds after the summer holidays. ${ }^{11}$ Learning gaps are a defining feature of underfunded education systems, which contribute to reproducing and cementing structures of poverty, marginalization and discrimination. Such structures are not caused by COVID-19 but rather deepened and exposed by the pandemic.

\section{Responding to the Pandemic: An Example of an Institutional Response}

The competition for influence and authority in the education space is nothing new, but the pandemic has intensified the need for actors to prove their relevance and propose solutions. UNESCO, the UN agency in charge of education, was quick to step up and assume the role of convenor when establishing a Global Education Coalition to 'facilitate inclusive learning opportunities for children and youth. ${ }^{12} \mathrm{~A}$ direct response to the sudden and urgent need to shift education online as schools were closing in one country after the

\footnotetext{
9 https://www.worldsofeducation.org/en/woe_homepage/woe_ detail/16697/\%e2\%80\%9cshould-we-continue-student-learning-during-covid 19-a-question-of-maslow-before-bloom \% 2\% 80\% 9d-byarmand-doucet. Accessed 10 June 2020.

10 https://www.teachers.ab.ca/News\%20Room/Issues/COVID-19/ Pages/Covid-19-Survey.aspx. Accessed 10 June 2020.

11 https://www.brookings.edu/research/summer-learning-loss-whatis-it-and-what-can-we-do-about-it/. Accessed 10 June 2020.

12 https://en.unesco.org/covid19/educationresponse/globalcoalition. Accessed 10 June 2020.
}

other, the Coalition is described as an 'open partnership' based on a 'commitment to help countries assure the inclusive and equitable provision of distance education'.

There is, however, an additional objective: 'Investment in remote learning should both mitigate the immediate disruption caused by COVID-19 and establish approaches to develop more open and flexible education systems for the future', ${ }^{13}$ positioning edtech as the emergency response but also a long-term solution. Much of the hype around technology in education is based on exactly this assumption, that it will enable a system-level transformation, where current education practices are rethought and replaced with something more innovative. But there is nothing inherently transformative about technology. In fact, algorithms have been shown to reproduce structures of racism exactly by virtue of repeating learned patterns of behaviour.

The focus on facilitating online learning made providers of education technology the primary target for membership of the Coalition, that is, the private sector, with the implicit understanding that UN Member States would benefit from the services offered. Organizations interested in joining are asked to 'specify what free support, tools or services they can offer countries that might help them extend educational opportunities during periods of school closure'. ${ }^{14}$ While cost of course constitutes a primary barrier, and many platforms and products were in fact made freely available to schools and education institutions in the past months, the mandate of UNESCO and the scope of SDG 4 raise a number of concerns in relation to edtech, which are discussed below.

It is, however, not clear what the Coalition has been doing in practice, which poses the question of whether it is a coordinated global response to the pandemic, or, rather, an initiative to showcase ongoing efforts of a range of different actors. Coupled with the public endorsement of several private companies and philanthropic organizations, UNESCO's Coalition is in fact helping create a market and opportunities for the private sector in education. Given its financial situation, the question is whether UNESCO perceives itself to have the political mandate and capital to enforce the values and principles of SDG 4. Could UNESCO have rejected the notion of edtech as a silver bullet and rather formed a Coalition around designing a rights-based response, looking at how inclusion, equity and quality are ensured in a pandemic?

\footnotetext{
${ }^{13}$ https://en.unesco.org/covid19/educationresponse/globalcoalition. Accessed 10 June 2020.

14 https://en.unesco.org/covid19/educationresponse/globalcoalition. Accessed 10 June 2020.
} 


\section{Edtech: A Solution to all Problems}

Proponents of technology in education frame it as a quick fix to make education more inclusive, innovative and affordable. The assumption is that all teaching and learning simply can be moved online, it is just a matter of finding the right tool. While technology has been vital during the school closures, there are several issues to consider in relation to equity, inclusion and quality.

First of all, technology is not a neutral tool. Edtech is contextual and shaped by a range of assumptions, preferences and biases, exactly like the curricula and other educational materials. Our understanding of what constitutes knowledge and how it should be taught cannot be separated from its socio-political, economic and historical contexts. As recognized by Education International in its resolution on Decolonising education: 'knowledge and ways of learning can be considered 'colonised' in the sense that knowledge systems produced and ways of learning valued by colonising powers have historically been, and continue to be, powerful and often dominant over knowledge systems produced and ways of learning valued by (previously or currently) colonised peoples and Indigenous Peoples'. ${ }^{15}$ What this means in practice is that the 'helpful' tools designed (by white men) in a corner of the Global North may not be appropriate across contexts and may undermine the quality and relevance of education.

The rapid shift to online teaching also created a marketplace for lesson plans and materials. I am here not referring to the professional collaboration of teachers, but rather to the market opportunity spotted, as exemplified by Amazon's new initiative, Amazon Ignite, where teachers can sell their educational resources to their colleagues. A clever way of targeting an underpaid workforce, inviting them into the gig economy, while charging teachers $30 \%$ of the sales plus a transaction fee. ${ }^{16}$

Second, not all technology is suitable for teaching and learning, as has also been demonstrated in the past months, where online classes and lectures have been disrupted by zoombombing, ${ }^{17}$ for example. Teachers report that the digital technologies have a negative impact on their health and wellbeing, citing workload intensification and poorer work-life balance as the main concerns (Colclough 2020: 38). In times where the professional autonomy of teachers is curtailed in many places, the surveillance opportunities embedded in some of the edtech tools also raise alarm. Greek teachers'

\footnotetext{
15 https://www.ei-ie.org/en/detail/16361/resolution-on-decolonisingeducation. Accessed 10 June 2020.

16 https://ignite.amazon.com/\#/. Accessed 10 June 2020.

17 https://en.wikipedia.org/wiki/Zoombombing. Accessed 10 June 2020.
}

unions have protested against a law on the streaming of onsite teaching for students who can't attend school due to COVID-19 restrictions, arguing that it violates their rights to privacy and professional autonomy. ${ }^{18}$ Many unions are concerned about privately provided online platforms and their implications for data protection and the privacy rights of both students and teachers. Another question pertains to copyright restrictions and ownership of materials and resources for teaching and learning developed by teachers and shared through online platforms.

Third, there is often a lack of understanding of technology and its potential and pitfalls by those who make decisions in education. Many experts have cautioned against the long-term impact and consequences of what seem to be generous offers from edtech companies to ensure free access to schools and education institutions during the pandemic (Williamson and Hogan 2020). Tools and platforms are likely to be introduced as emergency measures, chosen without any transparency or accountability, and risk becoming normalized in the education sector and integrated to an extent that makes it hard to reverse the choice of platform.

The changing role of the government is at the core of this situation: the sudden and desperate demand for tech solutions combined with a generally poor understanding of the opportunities, risks and dangers of tech platforms makes for a situation wherein the tech provider has the power; the people who will use the tools - teachers and students-are sidelined; and the public authority struggles to assert its role as the guarantor of quality education. This is particularly pertinent in relation to international commercial actors assuming the roles of providers and/or policymakers across local contexts. As edtech providers now assume a new role as key players in the global education policy space, governance grows ever more complex-frustrating efforts at transparency and accountability.

\section{A Changing Education Financing Landscape}

The concerns about the role and involvement of private actors in the response to the pandemic must be seen in the context of underfunded and overburdened public education systems. While the situation varies across countries-from largely privatized to predominantly public provision of education - there has been a growing trend towards privatization and commercialization in recent years (Verger et al. 2016), including through 'alternative forms of educational

\footnotetext{
18 https://www.csee-etuce.org/en/news/member-organisations/3851greece-greek-government-bypass-social-dialogue-mechanisms-andadopts-regulation-on-live-streaming-delivery-of-lessons. Accessed 10 June 2020.
} 
provision (including e-learning), test preparation services, edu-marketing, the provision of curriculum packages, private tutoring and other supplemental education services, certification services, teacher training, recruitment of university students, and school improvement services' ${ }^{19}$ As in other sectors, privatization is framed as 'a technical solution for managing resources and reducing fiscal deficits' (UN 2018: 2).

The lack of financing is one of the principal reasons for the failure to meet earlier education goals (UNESCO 2015a), as was also reflected in the advocacy for an education financing target as part of the SDGs (Wulff 2020). Even if the 2030 Agenda is silent on public finance, the Education 2030 Framework for Action, adopted by UNESCO Member States in November 2015, calls for an allocation of 'at least $4 \%$ to $6 \%$ of ... GDP' and 'at least $15 \%$ to $20 \%$ of public expenditure' to education (UNESCO 2015b: 67). This is, in fact, a decrease in the level of ambition; in 2000, the demand was $6 \%$ and $20 \%$, respectively.

Such an adjustment in ambition reflects the global discourse around development finance generally and education spending more specifically, where public funds are framed as insufficient and private finance as a necessity (World Bank 2015; UNGA 2015; see also ITUC 2020). This makes for a political landscape where any demands on governments to fulfil their role as duty-bearers are considered unreasonable-as if it were impossible to imagine a government ensuring free quality public education for all, without any involvement by the private sector.

The notion of public funds as finite is a deeply ideological one. Yet, it is pervasive, particularly when supported and coupled by institutions such as the World Bank and its machinery of loans as well as policy advice (ITUC 2020). States are pushed to shift fiscal resources towards attracting foreign investment, away from public services, and are encouraged to consider privatization and blended finance.

The World Bank made an unexpected turn earlier this year when it decided to freeze all direct or indirect investments in private for-profit pre-primary, primary and secondary schools. ${ }^{20}$ The International Finance Corporation (IFC) will now have to carry out an evaluation as well as a consultation process in order to "determine whether there are any exceptional circumstances under which future IFC investments in such schools could be made without impacting negatively on poverty, inequality, the right to education,

\footnotetext{
19 https://www.ei-ie.org/en/woe_homepage/woe_detail/4850/the-riseof-the-global-education-industry-some-concepts-facts-and-figures. Accessed 10 June 2020

${ }^{20}$ https://www.worldsofeducation.org/en/woe_homepage/woe_detail/ 16731/world-bank-shifts-position-on-funding-for-most-private-forprofit-schools-by-david-edwards. Accessed 10 June 2020.
}

or the provision of public education'. ${ }^{21}$ The areas on which impact have to be assessed go beyond what might have been expected-for once, the attention will have to be on the extent to which the public sector is negatively impacted, rather than obsessing over any negative impact on the private sector, which tends to be the usual practice within the Bank.

However, in the meantime the Bank will carry on its policy advice and technical work-which some have suggested is in fact more effective in fostering change. ${ }^{22}$ Looking at the education sector, the Bank has over the past decade actively promoted privatization, decentralization and market-based reforms; Mark Ginsburg and Steven Klees describe its technical work as having a neoliberal ideological bias, exemplified by policy proposals such as 'pay for performance, de-professionalizing teachers, narrow learning outcome assessments, consumer-producer type accountability, reducing central government's role, and privatizing provision of schooling, ${ }^{23}$ In practice, countries are recommended to expand the private provision of education and limit its regulation; in the case of Nepal, this included specific recommendations on direct funding and incentives for private providers. ${ }^{24}$

This ideological bias also shapes the World Bank's reaction to the pandemic: it is concerned about the education market and the loss of income for private education providers as the economic consequences of the pandemic hit households, and families find themselves unable to pay tuition fees. Again, the Bank is calling upon governments to step in and support private providers through school fee waivers. However, as part of its COVID-19 response, the Bank is also calling for safeguarded education spending, recognizing that '[i]ncreased education spending can be an important part of fiscal stimulus packages' (World Bank 2020: 35). This builds on its new emphasis on the role of governments in boosting human capital in order to foster economic growth. ${ }^{25}$

Researching the impact of the pandemic on privatization and commercialization in education, Ben Williamson and Anna Hogan (2020: 2) identify a 'global edtech industry

\footnotetext{
${ }_{21} \mathrm{https}: / /$ financialservices.house.gov/uploadedfiles/malpass_ltr_ mnuchin_3202020.pdf. Accessed 10 June 2020 .

22 https://www.brookings.edu/blog/future-development/2020/05/19/ what-makes-the-world-bank-so-influential-its-money-or-its-ideas/. Accessed 10 June 2020.

${ }^{23}$ https://www.ei-ie.org/en/woe_homepage/woe_detail/16508/saber exposed-the-world-banks-saber-a-knowledge-source-or-an-ideologica lly-honed-weapon-to-compel-neoliberal-educational-reforms-bymark-ginsburg-and-steven-klees. Accessed 10 June 2020.

${ }^{24}$ https://www.ei-ie.org/en/woe_homepage/woe_detail/16527/saber exposed-engaging-the-private-sector-by-brendan-decoster. Accessed 10 June 2020.

25 https://www.worldbank.org/en/publication/human-capital. Accessed 10 June 2020.
} 
solutionism', where private and commercial actors have 'set the agenda, offered technical solutions for government departments of education to follow, and is actively pursuing long-term reforms'. The pandemic and the shift to online learning has accelerated a development that was already underway; according to HolonIQ, a hub for global education market intelligence, global edtech attracted US $\$ 16,1$ billion of venture capital in 2020, 32 times more than it attracted in 2010, which they frame as backing a vision to transform the way the world learns and supporting the Sustainable Development Goal four (SDG 4). ${ }^{26}$ In January 2019, it estimated that education expenditure- 'from governments, parents, individuals and corporates'-would continue to grow and reach US $\$ 10$ trillion by 2030 , compared to US $\$ 6.5$ trillion in 2020.

What is emerging is an ever more complex landscape. Williamson and Hogan (2020: 47) describe the situation as:

a huge effort to create multisector coalitions and networks in which commercial actors play a key part, and we have seen the development of a range of interdependencies between various organizational typesfrom multilateral policy influencers, wealthy tech philanthropies and government departments to global technology corporations, edu-businesses, venture capital investors, and public institutions.

What this demonstrates is a changing global education policy landscape, where new actors, many of whom are profit-driven, are positioning themselves as key players in the global policy space. This places new demands on the state as the duty-bearer and the guarantor of quality education for all. The public regulation of education is key to quality and equity, but national standards may be difficult to enforce in a context of multiple actors and service providers. While the privatization and commercialization in and of education are not new phenomena, the sector is largely unprepared for the gig economy, the platform economy, and commercial efforts related to data mining and big data, placing governments at a further disadvantage in terms of regulating and enforcing standards.

\section{Re-thinking and Reinforcing Global Governance to Protect Education as a Public Good}

What I have argued here is that the diversification of power and influence in the global education policy space has coincided with a shift in the broader global governance of

\footnotetext{
${ }^{26} \mathrm{https} / / / \mathrm{ww} w . h o l o n i q . c o m /$ notes/16.1b-of-global-edtech-venturecapital-in-2020/. Accessed 8 April 2021.
}

development, where states and the private sector are framed as being equally important for the achievement of the SDGs. This represents a fundamental renegotiation and weakening of the role of the state, which, coupled with the absence of accountability and financing commitments, directly undermines the transformative ambition of the agenda.

The 'all-implementation-is-good-implementation' approach is a spectacular failure of global governance to defend and reinforce the values and principles of the 2030 Agenda. Since the onset of the pandemic, the UN has underlined the need for a new social contract and has called for 'macroeconomic choices and fiscal policies that are propoor and place peoples' rights at the center, [and] greater investment in public services and other measures that curb inequalities'. ${ }^{27}$ This would require a reimagination of the current follow-up and review of the 2030 Agenda and the introduction of an accountability structure that would enable a consideration of the economic, social and environmental consequences of policy and financing modalities.

But it would also require a reimagination of the role of global governance: what would a new social contract at the global level look like? How can global institutions reinforce the values and principles of the 2030 Agenda? The globallevel follow-up and review should be a forum for addressing the systemic barriers to progress, with a focus on those that reproduce the inequality between countries and enforce the unequal access to resources as well as decision-making and global economic governance.

As the world is entering into a global recession, high public debt levels and tightened financing conditions are exacerbating pressures on national budgets. This at a moment when public service expenditure was already declining in many regions and projected to continue dropping. ${ }^{28}$ For countries to have the necessary fiscal space to deliver on SDG 4, there will have to be significant debt relief and cancellation and a shift away from market-based approaches to development. The normalization of austerity cannot continue and the legitimacy of public financing options should be reasserted and reinforced.

The pandemic has put into stark relief the need for strengthened government action, across sectors and silos. At this time, strengthening public education systems must be recognized as an essential part of a people-centred and rights-based response to the pandemic, realizing rights while investing in livelihoods and protecting jobs. Global governance should emphasize education as a public good and the public provision and regulation of education as key

\footnotetext{
27 https://unsdg.un.org/sites/default/files/2020-04/UN-frameworkfor-the-immediate-socio-economic-response-to-COVID-19.pdf. Accessed 10 June 2020.

${ }^{28}$ https://eurodad.org/outofservice. Accessed 10 June 2020.
} 
to quality and equity in education, particularly in contexts with multiple providers.

What is missing in global governance is a conversation about the suitability of privately financed public goods, an acknowledgement of the politics of financing and a consideration of its implications for the social contract. So long as sources of financing are framed as a mere practical arrangement, people and their rights and dignity will be considered secondary.

\section{References}

Benavot, Aaron, and William C. Smith. 2020. 'Reshaping Quality and Equity: Global Learning Metrics as a Ready-made Solution to a Manufactured Crisis'. In Antonia Wulff (ed.), Grading Goal Four: Tensions, Threats and Opportunities in the Sustainable Development Goal on Education. Leiden: Brill I Sense.

Colclough, Christina. 2020. Teaching with Tech: The role of education unions in shaping the future. Brussels: Education International.

Feiring, Birgitte, and Adrian Hassler. 2016. Human Rights in Followup and Review of the 2030 Agenda for Sustainable Development. Copenhagen: Danish Institute for Human Rights.

ITUC. 2020. Market Fundamentalism and the World Bank Group: from Structural Adjustment Programmes to Maximising Finance for Development and Beyond. Brussels: ITUC.

Sayed, Yusuf, and Kate Moriarty. 2020. SDG 4 and the Education Quality Turn: Prospects, Possibilities, and Problems. In Antonia Wulff (ed.), Grading Goal Four: Tensions, Threats and Opportunities in the Sustainable Development Goal on Education. Leiden: Brill I Sense.

Scheicher, Andreas. 2019. PISA 2018 Insights and Interpretations. Paris: OECD.

UNESCO. 2015a. Education for All 2000-2015: Achievements and Challenges, Global Education Monitoring Report 2015. Paris: UNESCO.
UNESCO. 2015b. Education 2030: Incheon Declaration and Framework for Action for the Implementation of Sustainable Development Goal 4. Paris: UNESCO.

United Nations. 2018. Extreme poverty and human rights: Note by the secretary-general (Report of the Special Rapporteur on Extreme Poverty and Human Rights. A/73/396.) New York: UN.

United Nations General Assembly. 2015. Addis Ababa Action Agenda of the Third International Conference on Financing for Development (Addis Ababa Action Agenda). New York: UN.

Verger, Antoni, Christopher Lubienski, and Gita Steiner-Khamsi. 2016. World Yearbook of Education 2016: The Global Education Industry. New York: Routledge.

Williamson, Ben, and Anna Hogan. 2020. Commercialization and privatization in/of education in the context of Covid-19. Brussels: Education International.

World Bank. 2015. From Billions to Trillions: Transforming Development Finance. Washington, DC: World Bank.

World Bank. 2020. The COVID-19 Pandemic: Shocks to Education and Policy Responses. Washington, DC: World Bank.

Wulff, Antonia. 2019. The ideological battle over SDG 4. In Spotlight on Sustainable Development: Reshaping Governance for Sustainability. Bonn: The Reflection Group on the 2030 Agenda for Sustainable Development.

Wulff, Antonia. 2020. The Twists and Turns in Negotiating a Global Education Goal: A Civil Society Perspective. In Antonia Wulff (ed.), Grading Goal Four: Tensions, Threats and Opportunities in the Sustainable Development Goal on Education. Leiden: Brill I Sense.

Publisher's Note Springer Nature remains neutral with regard to jurisdictional claims in published maps and institutional affiliations. 